\title{
EFFECTIVENESS OF CHIROPRACTIC ADJUSTMENT IN LUMBAR PAIN IN CROSSFIT PRACTITIONERS
}

\author{
EFICÁCIA DO AJUSTE QUIROPRÁTICO NAS DORES LOMBARES EM PRATICANTES \\ DE CROSSFIT
}

\author{
EFICACIA DEL AJUSTE QUIROPRÁCTICO EN LOS DOLORES LUMBARES \\ EN PRACTICANTES DE CROSSFIT
}

Desiree Moehlecke ${ }^{1}$, Luiz Alberto Forgiarini Junior ${ }^{1}$

1. Centro Universitário Metodista-IPA, Porto Alegre, RS, Brazil.

\begin{abstract}
Objective: To evaluate the efficacy of acute chiropractic adjustment in individuals who practice CrossFit with regard to complaints of low back pain and the joint range of motion in this region. Methods: A randomized clinical trial comprised of CrossFit practitioners from a box in Novo Hamburgo-RS, of both sexes and aged 18 to 40 years who had low back pain at the time of the study. The following tools were used: Semi-structured Anamnesis Questionnaire, Visual Analog Scale, McGill Pain Questionnaire, and SF-36 Quality of Life Questionnaire. Individuals in the control group answered the questionnaires before and after CrossFit training. The chiropractic group performed the same procedure, plus pre-training chiropractic adjustment and joint range of motion (ROM) before and after lumbar adjustment. Results: There was a significant increase in pain in the control group, and a significant decrease in pain in the chiropractic group, including one day after the chiropractic adjustment. In the chiropractic group, the joint ranges of motion had a significant increase in flexion and extension of the lumbar spine after chiropractic adjustment. Conclusion: The chiropractic group achieved a significant improvement in pain level and joint range of motion, suggesting that acute chiropractic adjustment was effective in reducing low back pain.
\end{abstract}

Keywords: Physical exercise; Manipulation, chiropractic; Low back pain; Range of motion; articular.

\section{RESUMO}

Objetivo: Avaliar a eficácia do ajuste quiroprático agudo em indivíduos praticantes de CrossFit com relação às queixas de dores lombares e à amplitude de movimento articular nessa região. Métodos: Estudo clínico randomizado, composto por praticantes de CrossFit de um box de Novo Hamburgo/RS, de ambos os sexos e com idades de 18 a 40 anos que tinham dor lombar na ocasião da pesquisa. Foram usados os instrumentos Ficha de Anamnese Semiestruturada, Escala Visual Analógica, Questionário de dor McGill e Questionário de Qualidade de Vida SF-36. Os indivíduos do grupo controle responderam os questionários antes e depois do treino de CrossFit. O grupo quiropraxia realizou o mesmo procedimento, acrescido do ajuste quiroprático pré-treino e da medição da amplitude de movimento (ADM) articular antes e depois de ajuste lombar. Resultados: Observaram-se aumento significativo de dor no grupo controle e diminuição significativa de dor no grupo quiropraxia, inclusive um dia após o ajuste quiroprático. No grupo quiropraxia, as amplitudes de movimento articular tiveram aumento significativo na flexão e na extensão da coluna lombar após o ajuste quiroprático. Conclusão: O grupo quiropraxia obteve uma melhora significativa no nível de dor e na amplitude de movimento articular, sugerindo que o ajuste quiroprático agudo foi eficaz na redução da dor lombar.

Descritores: Exercício físico; Manipulação quiroprática; Dor lombar; Amplitude de movimento articular.

\section{RESUMEN}

Objetivo: Evaluar la eficacia del ajuste quiropráctico agudo en individuos que practican CrossFit con relación a las quejas de dolores lumbares y el rango de movimiento articular en esa región. Método: Ensayo clínico aleatorizado compuesto por practicantes de CrossFit de un box de Novo Hamburgo-RS, de ambos sexos y con edades de 18 a 40 años que tenían dolor lumbar en ocasión de la investigación. Se utilizaron los cuestionarios Ficha de Semi-estructurada de Anamnesis, Escala visual analógica, cuestionario de McGill y el Cuestionario de Calidad de vida SF -36. Los individuos del grupo control respondieron los cuestionarios antes y después del entrenamiento de CrossFit. El grupo quiropráctico realizó el mismo procedimiento, incrementado de ajuste quiropráctico pre-entrenamiento y de la medición del rango de movimiento (RM) articular antes y después de ajuste lumbar. Resultados: Se observó un aumento significativo de dolor en el grupo control y disminución significativa del dolor en el grupo quiropráctico, incluso un día después del ajuste quiropráctico. En el grupo quiropráctico, los rangos de movimiento articular tuvieron un aumento significativo en la flexión y extensión de la columna lumbar después del ajuste quiropráctico. Conclusión: El ajuste quiropráctico agudo logró una mejora significativa en el nivel de dolor lumbar y en el rango de movimiento articular, sugiriendo que el ajuste quiropráctico agudo fue eficaz en la reducción del dolor lumbar.

Descriptores: Ejercicio físico; Manipulación quiropráctica; Dolor de la región lumbar; Rango del movimiento articular. 


\section{INTRODUCTION}

Physical activity is advocated as an important tool in preventing the emergence of diseases, controlling already existing diseases, and for the well-being and social life of human beings. ${ }^{1,2}$ Sports and physical activity do not seem to be the main cause of spine pain and injuries, but the frequent additional load on the biological structures of the spine during high-impact sports may be a prerequisite for injury. The lumbar spine is the location with the highest incidence of injuries. . $^{3-5}$

Low back pain is one of the most common musculoskeletal conditions and the second most frequent reason that patients seek professional health care. In most cases, the lumbalgia is caused by mechanical problems in the joints and muscles. ${ }^{6-8}$

In CrossFit training, individuals perform repetitive movements of lifting weights, squatting, and improper posture,, 10 and an evaluation of whether these movements are being performed incorrectly during training, whether from carelessness or lack of guidance, is extremely important. These activities, when repeated frequently, can lead to spine problems and intense pain, especially in the lumbar region, where most of the weight is normally supported. ${ }^{11,12}$ The adoption of poor posture provokes muscular imbalance and limits joint amplitude, hindering normal ranges of joint movement and possibly triggering painful processes. ${ }^{13-15}$

Research on the effectiveness of chiropractic treatment for spine diseases has shown good results for low back pain reduction following chiropractic adjustment. ${ }^{16-20}$ It offers well-being to patients through pain relief, improved joint mobility, and muscle relaxation, ${ }^{17,18}$ providing quality of life, reducing medication use, and avoiding unnecessary surgeries. ${ }^{16,21,22}$

The objective of this study is to evaluate the effectiveness of acute chiropractic adjustment in individuals who practice CrossFit training, in relation to complaints of pain and range of joint movement in the lumbar region.

\section{METHODS}

This study was a randomized clinical trial conducted at a CrossFit box in Novo Hamburgo/RS (Ultimate CrossFit Pirates). It was approved by the Institutional Review Board of the Centro Universitário Metodista (IPA) as opinion 1.440.851. All the participants signed the informed consent form.

During March and April of 2016, all individuals, males and females between the ages of 18 and 40 years, enrolled at the CrossFit box who had low back pain at the time of the study were invited to participate. Individuals involved in any type of physical rehabilitation, drug treatment for pain, with any contraindication to chiropractic adjustment, who had a history of lumbar spine surgery, and those who did not answer the questionnaire within 24 hours of the chiropractic adjustment were excluded. We used the study by Mascarenhas and Santos $^{13}$ as a reference for calculating the sample size. The calculation was performed using WinPEPI ${ }^{\circledR}$, version 4.0 software, with a confidence level of $95 \%$, a coefficient of variation of $12 \%$, and acceptable margin of error of $5 \%$. Thus, 50 individuals were selected for the study, with 25 belonging to each of two groups. There were no exclusions in the study (Figure 1).

All 50 individuals who met the inclusion criteria were evaluated and randomized, using the online Research Randomizer, version 4.0 program (Social Psychology Network, http://www.randomizer.org), for the random allocation to the control and chiropractic groups. The individuals in the control group answered questionnaires both before and after CrossFit training. The chiropractic group followed the same procedure, with the addition of a chiropractic adjustment prior to training and the measurement of the range of motion (ROM) before and after the lumbar adjustment.

The whole procedure was conducted by two experienced researchers. The participants were properly positioned on the chiropractic table for one of the researchers to perform the high velocity low amplitude (HVLA) adjustment only to the lumbar region. The Diversified Technique was used, which, according to Cantera, ${ }^{23}$ is used to correct segments that present specific biomechanical changes, with the goal of restoring joint mobility. The other researcher

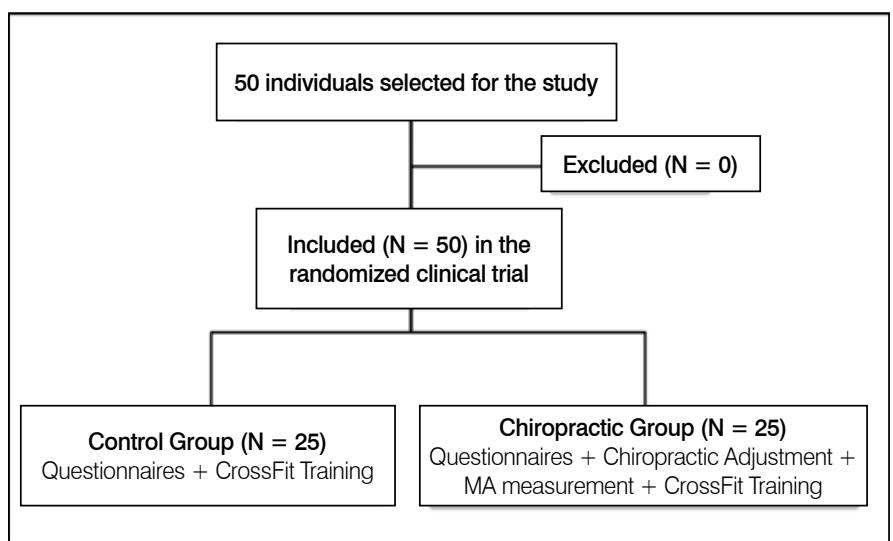

Figure 1. Flowchart of the individuals included in the study. MA - amplitude of joint movement.

measured the ROM before and after the chiropractic adjustment by means of inclinometers. For this, the individuals were standing and performed flexion and extension of the trunk with the inclinometers positioned above the spinous process of T12 and at the sacral level, thus obtaining the angle of the amplitude of movement of the spine. ${ }^{21}$ This measurement was conducted twice, resulting in an average.

In this study, we used the Visual Analog Scale (VAS) and the validated Portuguese language versions of the McGill Pain Questionnaire and the 36-item Medical Outcomes Study - Short Form (SF-36). The first questionnaire administered in both groups was the Semi-Structured Anamnesis Form. This was prepared by the first researcher, served as a screening tool, and contained standard data for each individual such as age, sex, weight, profession, time experiencing pain in the lumbar region, time practicing and frequency of CrossFit training, among others. Afterwards, they responded to the VAS, which served as a parameter to measure the condition of pain and to quantify the intensity and the individual perception of their pain. ${ }^{13,24}$ This scale was also applied to the chiropractic group 24 hours after the adjustment to assess whether there was any change in the pain profile.

Then, the individuals answered the McGill Pain Questionnaire, considered to be a universal tool able to standardize the language of pain and, lastly, the Generic Short Form Quality of Life Questionnaire (SF-36), with the goal of conducting a survey of the quality of life in relation to health. ${ }^{25-27}$

The initial outcome of the study was a data comparison between the control and chiropractic groups to confirm whether chiropractic adjustment is capable of reducing low back pain. Then, we evaluated the before and after responses of the control and the chiropractic groups. Finally, we compared the ROM data before and after the chiropractic adjustment in the chiropractic group.

All the continuous data were described as averages, standard deviations, and the categorical data as frequencies and percentages. Normality was measured using the Shapiro-Wilk test. For the comparison of the groups, we used the Student's t-test for paired samples or the Mann-Whitney test. The data were organized in an Excel (2007 version) database and analyzed using the Statistical Package for the Social Sciences for Windows 20.0 (SPSS), adopting a level of significance of $5 \%$.

\section{RESULTS}

Fifty individuals were included in the study between March and April, 2016. The subjects were predominantly male (58\%). The average age was $30 \pm 4.89$ years and the average BMI (body mass index) was $23.74 \pm 2.87 \mathrm{~kg} / \mathrm{m}^{2}$. The average daily workload was $8.24 \pm 0.81$ hours. Regarding CrossFit training, the time practicing was $16.02 \pm$ 12.25 months, with a frequency of $3.1 \pm 0.98$ days with an average training time of $66.6 \pm 12.43$ minutes. In terms of low back pain, the average time experiencing pain was $12.33 \pm 17.76$ months and $58 \%$ of the subjects had undergone some type of treatment (Table 1). 
There were no significant changes in relation to the general characteristics in the comparison between the groups. In the control group, $64 \%$ of the individuals had already undergone some form of treatment, the most commonly reported being physical therapy. In the chiropractic group, 52\% had already undergone treatment and the most commonly cited was chiropractic therapy itself (Table 2).

As for the pre- and post-training pain levels, we observed a significant increase in pain in the control group and a significant reduction in pain in the chiropractic group. The chiropractic group also experienced a reduction in pain on the day after the chiropractic adjustment (Figure 2).

In the chiropractic group, the amplitudes of articular movement had a significant increase in flexion and extension of the lumbar spine following the chiropractic adjustment (Figure 3). No significant changes were observed between the groups for the variables of the SF-36 Quality of Life Questionnaire or for the McGill Pain questionnaire, both with $p>0.05$ (Table 3 ). Regarding the descriptive section of the McGill questionnaire, descriptors were chosen in all categories, however, in the "sensitive" pain category we observed a repeating pattern of characteristics of the type of low back pain, with descriptors like "stabbing" and "shooting" being used with more frequency, 22 (44\%) and 19 (38\%) times, respectively.

Table 1. Characteristics of the individuals included in the study

\begin{tabular}{c|c}
\hline Variable & $\mathbf{n}=\mathbf{5 0}$ \\
\hline Age (years) & $30 \pm 4.89$ \\
\hline Sex & $21(42)$ \\
\hline Female & $29(58)$ \\
\hline Male & $23.74 \pm 2.87$ \\
\hline BMI (kg/m $\left.{ }^{2}\right)$ & $8.24 \pm 0.81$ \\
\hline Workload (hours) & \\
\hline CrossFit & $16.02 \pm 12.25$ \\
\hline Time practicing (months) & $3.1 \pm 0.98$ \\
\hline Frequency (days) & $66.6 \pm 12.43$ \\
\hline Training time (minutes) & $12.33 \pm 17.76$ \\
\hline Low Back Pain & $29(58)$ \\
\hline Time of pain (months) &
\end{tabular}

Data expressed as averages \pm standard deviation and number (\%). BMI - Body Mass Index.

Table 2. Characteristics of the individuals in the Control Group $(n=25)$ and the Chiropractic Group $(n=25)$.

\begin{tabular}{|c|c|c|c|}
\hline Variables & $\begin{array}{l}\text { Control } \\
\text { group }\end{array}$ & $\begin{array}{c}\text { Chiropractic } \\
\text { group }\end{array}$ & p \\
\hline Age (years) & $29.76 \pm 4.89$ & $30.84 \pm 4.83$ & 0.421 \\
\hline \multicolumn{4}{|l|}{ Sex } \\
\hline Female & $12(48)$ & $9(36)$ & \\
\hline Male & $13(52)$ & $16(64)$ & \\
\hline BMI $\left(\mathrm{kg} / \mathrm{m}^{2}\right)$ & $23.23 \pm 2.88$ & $24.27 \pm 2.76$ & 0.208 \\
\hline Workload (hours) & $8 \pm 0.89$ & $8.48 \pm 0.64$ & 0.074 \\
\hline \multicolumn{4}{|l|}{ CrossFit } \\
\hline Time practicing (months) & $15.9 \pm 14.1$ & $16.08 \pm 10.06$ & 0.958 \\
\hline Frequency (days) & $2.88 \pm 0.95$ & $3.32 \pm 0.97$ & 0.111 \\
\hline Training time (minutes) & $66 \pm 12.00$ & $67.2 \pm 12.81$ & 0.733 \\
\hline \multicolumn{4}{|l|}{ Low back pain } \\
\hline Time of pain (months) & $9.8 \pm 13.16$ & $15.2 \pm 21.58$ & 0.288 \\
\hline Undergone treatment & $16(64)$ & $13(52)$ & \\
\hline
\end{tabular}

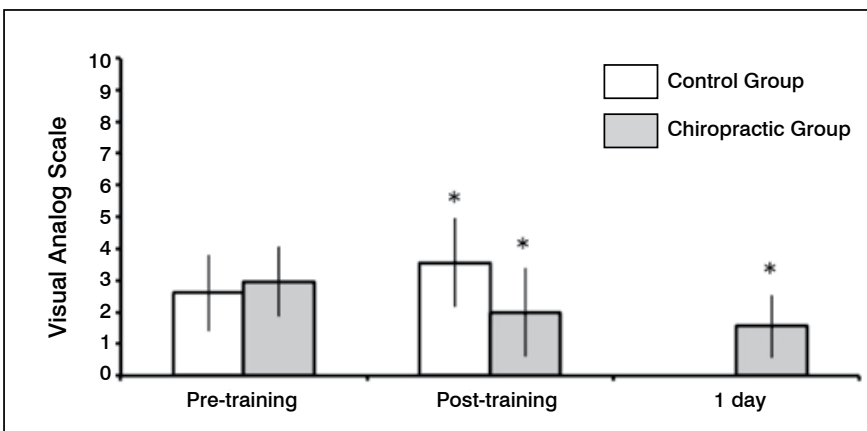

*pre-training vs. post-training control group $p<0.05$; post-training vs. 1 day after training chiropractic group $p<0.05$

Figure 2. Pain level of the Control Group (white) and the Chiropractic Group (grey).

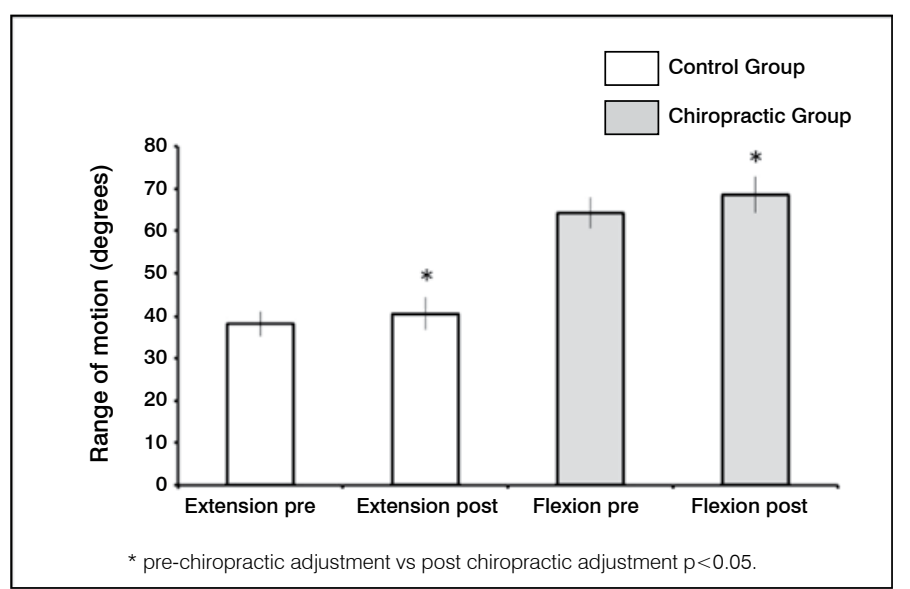

Figure 3. Evaluation of the Amplitude of Joint Movement in the Chiropractic Group.

Table 3. Evaluation of the SF-36 Quality of Life Scale and the McGill Pain Questionnaire in the Control Group and the Chiropractic Group $(n=50)$.

\begin{tabular}{c|c|c|c}
\hline Variable & Control group & $\begin{array}{c}\text { Chiropractic } \\
\text { group }\end{array}$ & $\mathbf{p}$ \\
\hline Quality of Life & & & \\
\hline FC & $95.2 \pm 5.5$ & $95 \pm 7.6$ & 0.915 \\
\hline LAF & $39 \pm 17.4$ & $42 \pm 16.9$ & 0.528 \\
\hline P & $69.8 \pm 16.4$ & $60.9 \pm 17.0$ & 0.062 \\
\hline GSH & $73.12 \pm 11.8$ & $78.6 \pm 15.2$ & 0.145 \\
\hline V & $66.6 \pm 15.5$ & $63.8 \pm 14.9$ & 0.493 \\
\hline SA & $85.2 \pm 16.8$ & $81.9 \pm 22.4$ & 0.547 \\
\hline LEA & $75.9 \pm 34.6$ & $55.9 \pm 44.9$ & 0.078 \\
\hline MH & $63.2 \pm 10.9$ & $62.2 \pm 11.5$ & 0.738 \\
\hline Total & & & \\
\hline McGill questionnaire & & & \\
\hline Index & $10.2 \pm 8.3$ & $10 \pm 6.9$ & 0.991 \\
\hline
\end{tabular}

$\mathrm{FC}=$ functional capacity; $\mathrm{LPA}=$ limitations from physical aspects; $\mathrm{P}=$ pain; $\mathrm{GSH}=$ general state of health; $\mathrm{V}=$ vitality; $\mathrm{SA}=$ social aspects; $\mathrm{LEA}=$ limitations from emotional aspects; $\mathrm{MH}=$ mental health.

\section{DISCUSSION}

The overall average age of the subjects was approximately 30 years and the average BMI was normal according to the Brazilian Association for the Study of Obesity (ABESO). ${ }^{28}$ Males were predominant in both groups, accounting for $58 \%$ of the total sample, corroborating findings in the literature that report that the modalities most practiced by men aiming to improve health and performance are those that involve lifting weights, such as body building. ${ }^{29}$ 
Of the 50 subjects, $58 \%$ had received some form of treatment, the most common of which was chiropractic therapy $(51.72 \%)$ followed by physical therapy (48.27\%). Chiropractic therapy is considered a primary treatment and the literature affirms that spine pain is the most common reason that patients use complementary and alternative therapies like chiropractic therapy, massotherapy, and acupunture. ${ }^{30,31}$ In a randomized clinical trial, Giles and Muller ${ }^{32}$ compared the efficacy of spine manipulation, medications, and acupuncture in patients with cervical and lumbar pain. They concluded that, if there were no contraindications, manipulation generates a reduction in pain and an increase in joint mobility. Other studies have evaluated the efficacy of other forms of treatment to reduce lumbalgia, such as trunk exercises to prevent and treat low back pain, but approaches that use mobilizations and manipulations significantly reduce low back pain. . $^{33,34}$

The results we obtained in reducing pain levels are similar to those found in the literature ${ }^{35-38}$ and affirm that procedures that use joint manipulations have a rapid physiological effect on the body, promoting an overal reduction of muscular spasms of the spine and causing chemical, mechanical, and thermal changes resulting in a response reflex and causing analgesia at the site of the adjustment, consequently reducing the pain..$^{38-41}$

Manipulation of the spine causes changes in the musculoskeletal system. Experimental evidence indicates that the impulse load of spine manipulation influences the primary proprioceptive afferent neurons of the paraspinal tissues. ${ }^{42}$ In addition, vertebral manipulation may possibly affect the pain process, changing the central state of facilitation of the spinal cord, and it can affect the motor control system. ${ }^{42,43}$

Patients with acute or chronic pain have relevant and statistically significant clinical improvement in all spinal structures following chiropractic manipulation. ${ }^{39}$ The control group had an increase in pain level following training, reinforcing the findings in the literature where weight lifting has been widely associated with lumbalgia. ${ }^{44,45}$

The average measurement of the lumbar ROM agrees with that found in the literature, both in movements of flexion and extension. ${ }^{21,46,47}$ The significant increase in the flexion and extension of the lumbar spine following chiropractic adjustment is in accordance with a study that showed that vertebral manipulation can improve joint mobility and restore movement in all anatomical planes, thus serving to eliminate the kinesiopathological component of the vertebral subluxation complex. ${ }^{48}$

When we analyzed the quality of life of the subjects included in the study, we observed an excellent score in the area of functional capacity in both groups, which was to be expected since the sample was made up of people who participate in regular physical activities and are in good physical health. The general state of health also received a high score. The individuals had chronic pain, but of low intensity, which interfered less with the quality and emotional aspects of their lives when regular physical activity was included.

Chronic non-specific low back pain is rarely related to total disability in performing a person's daily activities. However, it may cause partial and temporary, and many times recurring, limitations. ${ }^{49}$ This fact corroborates our finding that complaints of pain in the lumbar region was not seen as a factor causing disability in the individuals, but rather as a limitation to performing certain daily activities.

In the McGill Pain Questionnaire, the "sensitive" category was checked by $100 \%$ of the sample, as similar to the literature where this category is the most cited. ${ }^{50,51}$ In the study by Gonçalves, ${ }^{50} 99 \%$ of the subjects reported the lumbosacral zone as the most affected region, and "uncomfortable" is among the words most often cited. In the study by Bermudez and Bontempo ${ }^{51}$ one of the most frequently used words, in the sensory subclass, is "sore". The sensory category refers to the mechanical, thermal, and spatial properties and vividness of the pain, ${ }^{13}$ demonstrating that in this study the subjects were successful in characterizing their pain, indicating a pain of mainly physical origin. In contrast to the results of the studies cited above, in our study, the most frequently used descriptors were words like "stabbing" and "shooting", although they are all part of the same "sensory" category.

There are some aspects of this study that need to be taken into consideration. First, the VAS used to measure the perception of pain may reveal a subjective and placebo effect of pain, given that the participants had access to their previous level of pain. Second, the control group was not evaluated for the post-training pain level, since there was no ROM measurement or chiropractic adjustment in this group. It might be interesting to have this value, since CrossFit is an impact physical activity that can lead to peaks of muscle pain in the 24 hours following the exercise.

\section{CONCLUSION}

Acute chiropractic adjustment (HVLA - Diversified Technique) was shown to be effective in reducing the perception of lumbar pain and in improving the amplitude of joint movement in individuals who practice CrossFit training with complaints of low back pain.

All authors declare no potential conflict of interest related to this article.

CONTRIBUTION OF THE AUTHORS: Each author made significant individual contributions to this manuscript: DM to the concept of the study, data collection, and writing of the final article; LAFJ to the concept of the study, data analysis, and final review of the article.

\section{REFERENCES}

1. Martins R. Exercício Físico e Saúde Pública. Lisboa: Livros Horizonte; 2006

2. Luz TDA. Análise da atividade física e qualidade de vida em estudantes de ciências do desporto [dissertação]: Coimbra: Universidade de Coimbra, Setembro; 2015.

3. Salter RB. Distúrbios e lesões do sistema musculoesquelético. $3^{\mathrm{a}}$. ed. Rio de Janeiro: Medsi; 2001

4. Zatsiorsky VM. Biomecânica no esporte - performance do desempenho e prevenção de lesão. Rio de Janeiro: Guanabara Koogan; 2004.

5. Hak PT, Hodzovic E, Hickey B. The nature and prevalence of injury during CrossFit training J Strength Cond Res. 2013 Nov 22. [Epub ahead of print] PubMed PMID: 24276294

6. Evans RC. Exame físico ortopédico ilustrado. 2a . ed. São Paulo: Manole; 2003.

7. Matos MG, Hennington EA, Hoefel AL, Dias-da-Costa JS. Dor lombar em usuários de um plano de saúde: prevalência e fatores associados. Cad Saúde Pública. Rio de Janeiro. 2008;24(9):2115-22.

8. Cipriano A, Almeida DB, Vall J. Perfil do paciente com dor crônica atendido em um ambulatório de dor de uma grande cidade do sul do Brasil. Rev Dor. 2011:12(4):297-300.

9. Paine J, Uptfraft J, Wylie R. CGSC CrossFit Study: a study prepared for Command and General Staff College of the United States Army. 2010. Disponível em: http://cgsc.cdmhost.com/cdm/singleitem/collection/p124201 coll2/id/580/rec/1

10. Weissenthal BM, Beck CA, Maloney MD, DeHaven K, Giordano BD. Injury Rate and Patterns Among CrossFit Athletes. Orthop J Sports Med. 2014;2(4):2325967114531177.

11. Verbunt JA. Reliability and validity of the PAD questionnaire: a measure to assess pain-related decline in physical activity. J Rehabil Med. 2008:40(1):9-14

12. Joondeph SA, Joondeph BC. Retinal Detachment due to CrossFit Training Injury. Case Rep Ophthalmol Med. 2013;2013:189837.

13. Mascarenhas CHM, Santos LS. Avaliação da dor e da capacidade funcional em indivíduos com lombalgia Crônica. J Health Sci Inst. 2011;29(3):205-8.

14. Almeida TT, Jabur NM. Mitos e verdades sobre flexibilidade: reflexões sobre o treinamento de flexibilidade na saúde dos seres humanos. Motricidade. 2007:3(1):337-44

15. Graup S. Desvios posturais na coluna lombar e a relação com dor, mobilidade articular e atividade física em adolescentes [dissertação]. Santa Catarina: Universidade Federal de Santa Catarina; 2008

16. Chapman-Smith DA. Quiropraxia uma profissão na área da saúde: educação, prática, pesquisa e rumos futuros. São Paulo: Anhembi Morumbi, 2001

17. Munhós LM. A Quiropraxia e distúrbios osteomusculares: uma intervenção no quadro de funcionários do Centro Universitário Feevale [monografia]. Novo Hamburgo: Centro Universitário FEEVALE; 2006.

18. Rauber CP. A eficácia do ajuste cervical quiroprático em pacientes portadores de LER/ DORT [monografia]. Novo Hamburgo: Centro Universitário FEEVALE; 2007.

19. Johnson C. Comparative effectiveness research and the chiropractic profession. J Manipulative Physiol Ther. 2010;33(4):243-50.

20. Bergmann TF, Peterson DH, Lawrence DJ. Chiropractic technique: principles and procedures. 3rd. Philadelphia: Mosby; 2011. 
21. Cipriano JJ. Manual fotográfico de testes ortopédicos e neurológicos. $5^{a}$ ed. Porto Alegre: Artmed; 2012.

22. OMS - Organização Mundial de Saúde. Diretrizes da OMS sobre a formação básica e a segurança em Quiropraxia. Novo Hamburgo: Feevale; 2006.

23. Cantera CL. Palpaçao: técnicas e procedimentos quiroprácticos. Novo Hamburgo: Feevale; 2006.

24. Martinez JE, Grassi DC, Marques LG. Análise da aplicabilidade de três instrumentos de avaliação de dor em distintas unidades de atendimento: ambulatório, enfermaria $e$ urgência. Rev Bras Reumatol. 2011;51(4):304-8.

25. Ferreira PL. Criação da versão Portuguesa do MOS SF-36 - Parte I: Adaptação cultural e lingüística. Acta Med Port. 2000;13:119-27.

26. Severo M, Santos AC, Lopes C, Barros H. Fiabilidade e validade dos conceitos teóricos das dimensões de saúde física e mental da versão portuguesa do MOS SF-36. Acta Med Port. 2006;19:281-8.

27. Gil JAN, Cabri J, Ferreira PL. Efetividade dos cuidados de fisioterapia em doentes ambulatórios com problemas lombares não específicos. Rev Port Saúde Pública. 2009;9:35-50.

28. ABESO. Associação Brasileira para o Estudo da Obesidade e da Síndrome Metabólica - Diretrizes brasileiras de obesidade 2009/2010. 3a․ ed. Itapevi, SP: AC Farmacêutica; 2009

29. Guerro PRS, Fachineto $S$. Efeitos de um programa de treinamento crossfit sobre composição corporal, força muscular e freqüência cardíaca de repouso em homens jovens adultos treinados. Rev Dig EFDeportes. 2016;20(213). Disponível em: http://www.efdeportes. com/efd213/efeitos-de-um-programa-de-treinamento-crossfit.htm

30. McMorland G, Suter E, Casha S, du Plessis SJ, Hurlbert RJ. Manipulation or microdiskectomy for sciatica? A prospective randomized clinical study. J Manipulative Physiol Ther. 2010;33(8):576-84

31. Cherkin DC, Sherman KJ, Deyo RA, Shekelle PG. A review of the evidence for the effectiveness, safety and cost of acupuncture, massage therapy and spinal manipulation for back pain. Ann Intern Med. 2003;138(1):898-906

32. Giles LG, Muller R. Chronic spinal pain: a randomized clinical trial comparing medication, acupuncture, and spinal manipulation. Spine (Phila Pa 1976). 2003:28(14):1490-502.

33. Lehman SL, Hoda W, Oliver S. Trunk muscle activity during bridging exercises on and of a swissball. Chiropr Osteopat. 2005;13(14):1-8.

34. Licciardone JC, Brimhall AK, King LN. Osteopathic manipulative treatment for low back pain: a systematic review and meta-analysis of randomized controlled trials. BMC Musculoskelet Disord. 2005;6(43):1-12.

35. Peterson DH, Bergmann TF. Chiropractic technique principles and procedures. Philadelphia: Mosby; 2002

36. Simmonds N, Miller P, Gemmel H. A theoretical framework for the role of fascia in manual therapy. J Bodyw Mov Ther. 2012:16(1):83-93.
37. Cao DY, Reed WR, Pickar JG. Effects of thrust amplitude and duration of high-velocity, low-amplitude spinal manipulation on lumbar muscle spindle responds to vertebral position and movement. J Manipulative Physiol Ther. 2013;36(2):68-77.

38. Gregoletto D, Martinez CMC. Efeito da manipulação vertebral em pacientes com cervicalgia mecânica. Coluna/Columna. 2014;13(4):269-74.

39. Peterson CK, Leemann S, Lechmann M, Pfirmann CW, Hodler J, Humphreys BK. Symptomatic magnetic resonance imaging-confirmed lumbar disk herniation patients: a comparative effectiveness prospective observational study of 2 age- and sex-matched cohorts treated with either high velocity, low-amplitude spinal manipulative therapy or imaging-guided lumbar nerve root injections. J Manipulative Physiol Ther. 2013;36(4):218-55.

40. Kolberg C, Horst A, Kolberg A, Bello-Klein A, Partata WA. Effects of high-velocity, low-amplitude manipulation on catalase activity in men with neck pain. J Manipulative Physiol Ther, 2010; 33(4):300-7.

41. Teodorczyk-Injeyan JA, Injeyan S, Ruegg R. Spinal manipulative therapy reduces inflammatory cytokines but not substances $\mathrm{P}$ production in normal subjects. J Manipulative Physiol Ther. 2006;29(1):14-21.

42. Pickar JG, Bolton PS. Spinal manipulative therapy and somatosensory activation. J Electromyogr Kinesiol. 2012;22(5):785-94.

43. Haavik H, Murphy B. The role of spinal manipulation in addressing disordered sensorimotor integration and altered motor control. J Electromyogr Kinesiol. 2012;22(5):768-76.

44. Pataro SMS. Lombalgia em trabalhadores de limpeza urbana [dissertação]. Bahia: Faculdade de Medicina da Bahia; 2011.

45. Petersen RS. Fatores do trabalho associados à lombalgia não específica, caracterizada no âmbito da resistência da musculatura extensora lombar, entre trabalhadoras de enfermagem de Unidade de Terapia Intensiva [dissertação]. Ribeirão Preto: Escola de Enfermagem de Ribeirão Preto, Universidade de São Paulo;2012.

46. Clarkson HM. Avaliação musculoesquelética: amplitude de movimento articular e força muscular manual. 2 ${ }^{\underline{a}}$ ed. Rio de Janeiro: Guanabara Koogan; 2002.

47. Magee DJ. Avaliação musculoesquelética. 5a Ed. São Paulo: Monole; 2010.

48. Keller TS, Colloca CJ, Moore RJ, Gunzburg R, Harrison DE. Increased multiaxial lumbar motion responses during multiple-impulse mechanical force manually assisted spinal manipulation. Chiropr Osteopat. 2006;14(1):2-8.

49. Bento AAC, Paiva ACS, Siqueira FB. Correlação entre incapacidade, dor - Roland Morris, e capacidade funcional - SF-36 em indivíduos com dor lombar crônica não específica. e-Scientia. 2009;2(1):1-18.

50. Gonçalves JMC. Expressão da dor, ansiedade e depressão em doentes com lombalgias recorrentes [tese]. Lisboa: Universidade Autônoma de Lisboa; 2015.

51. Bermudez CU, Bontempo EG. Caracterização da dor lombar em gestantes praticantes e não praticantes de exercício físico [monografia]. Brasília: Centro Universitário de Brasília; 2010. 